Article

\title{
Art Organisers as Commoners: On the Sustainability and Counter-Hegemonic Potential of the Bangkok Biennial
}

\author{
Bart Wissink $^{1, *}$ and Lara van Meeteren ${ }^{2}$ \\ ${ }^{1}$ Department of Public Policy, City University of Hong Kong, Hong Kong (SAR) \\ ${ }^{2}$ Independent Researcher, Hong Kong (SAR) and Thailand \\ * Corresponding author (bartwissink@me.com)
}

Submitted: 20 September 2021 | Accepted: 20 December 2021 | Published: 22 February 2022

\begin{abstract}
As part of a remarkable wave of perennial contemporary art events in Thailand, the Bangkok Biennial was organised for the first time in 2018. Without central curation or funding, the organisational strategy of this artist-led, open-access event was strikingly different from the state-organised Thailand Biennale and the corporate Bangkok Art Biennale that were inaugurated several months later. Through the eyes of the literature on "commoning" as a third way of organising next to the state and market, we explore the "common spaces" that the Bangkok Biennial has produced. Reflecting on arguments articulated in the introduction to this thematic issue, as well as on Chantal Mouffe's analysis of the detrimental nature of an "exodus strategy" for counter-hegemonic action, we focus on the connections-if any-of the Bangkok Biennial with the state and corporations. Specifically, we address the following research questions: What are the characteristics of the Bangkok Biennial as a common art event? Which connections with the state and market have its organisers developed? And what are the consequences of this strategy for its sustainability and counter-hegemonic potential? We conclude that the organisers have consciously resisted developing relationships with the state and market, and argue that this "exodus strategy" is a necessity in Thailand's socio-political setting. And while this strategy might endanger the sustainability of this biennial as an art event, we argue that at the same time it supports an infrastructure for counter-hegemonic action inside and-possibly more importantly-outside art.
\end{abstract}

\section{Keywords}

antagonism; art organiser as commoner; artist as organiser; Bangkok Biennial; biennial; common space; common; commoning; contemporary art; Thailand

Issue

This article is a part of the issue "The Politics and Aesthetics of the Urban Commons: Navigating the Gaze of the City, the State, the Market" edited by Peer Smets (Vrije Universiteit Amsterdam) and Louis Volont (Massachusetts Institute of Technology).

(C) 2022 by the author(s); licensee Cogitatio (Lisbon, Portugal). This article is licensed under a Creative Commons Attribution 4.0 International License (CC BY).

\section{Introduction}

"Why 'biennial' and not 'biennale'? The two words mean the same thing, just in different languages. None of us are Italian" (Bangkok Biennial, 2018). With this matter-of-fact statement on the last page of their Guide to Pavilions, initiators Lee Anantawat, Jeff Gompertz, and Liam Morgan clarified the reasons behind the precise naming of the Bangkok Biennial, which was about to take place for the first time from July through
September 2018. It was a sly dig at two other biennials that were to be inaugurated later that same year: the state-organised Thailand Biennale and the corporate Bangkok Art Biennale that both sport the "Italian" name. While such name-teasing in itself might be of minor importance-it is more tongue-in-cheek joke than serious criticism after all-it is symbolic for the attitude of the initiators of an event, "set up as a challenge to the authority of access to representation in art and curatorial practices" (Bangkok Biennial, 2018). As we will 
see, in Thailand that authority mainly rests with a state that appropriates art to communicate correct views of "Thainess," and with increasingly smooth corporations that have discovered art as a means to boost consumption and real estate values. In response, with others, the art organisers involved with the Bangkok Biennial follow a "third" way of organising that, in a growing literature, is analysed as a process of "commoning" (e.g., De Angelis, 2017; Stavrides, 2016; Volont, 2020). Adding "common spaces" to the art landscape, these "commoners" try to counter the appropriation of art by the state and corporations, and to broaden the public sphere through the production of spaces for imagining different ways of being and living together.

In Thailand, as in other countries in the region, there is a tradition of art commoning, befitting ideas about the importance of the artist as organiser (McKee, 2017). We aim to reflect on the counter-hegemonic potential of these common art initiatives vis-à-vis the state and market in Thailand. Following the discussion of Volont and Smets (2022) in the introduction to this thematic issue, we will especially focus on the relationships that the Bangkok Biennial organisers have established with the state and corporations. After all, as these authors have pointed out (Volont \& Smets, 2021), while establishing such relationships might risk appropriation of common practices, without them the sustainability of common spaces is at risk. We will bring these arguments in conversation with Mouffe (2013), who stresses that art practices can play a crucial role in counter-hegemonic struggle as they help breed alternative subjectivities. In response to "exodus strategies" advocated by Virno (2004) and Hardt and Negri (2009), Mouffe is adamant that this struggle needs to play out in all institutional domains of society, including in art spaces and events led by the state and market. Using the Bangkok Biennial as an example, we examine how these dynamics play out for art initiatives in Thailand.

We write this article in the conviction that in today's setting of radical appropriation of art by the state and market there is an urgent need to explicitly address the counter-hegemonic potential of common art initiatives. With limited archiving and resources mostly directed towards state- and corporate-run events, common initiatives have not been sufficiently theorised, which might eventually hurt their potential. We aim to help change this by contributing to the scholarship on independent artist-led organising, a scholarship that-we are happy to see-is starting to grow in recent years (e.g., Teh, 2018). We do so through the following research questions: What are the characteristics of the Bangkok Biennial as a common art event? Which connections with the state and market have its organisers developed? And what are the consequences of this strategy for its sustainability and counter-hegemonic potential?

We address these research questions in the following six sections. First, we will turn our attention to Thailand, introducing the context within which its con- temporary art practices in general and biennials in particular function. Then we will present commoning as a third way of social organisation next to the state and market. Developing the arguments introduced above, we wonder if common initiatives should engage with the state and market. We will also reflect on the relevance of this discussion for the Thai context. In the following section we present the methodological choices that have guided our research. Next, we turn our attention to the Bangkok Biennial itself, discussing its organisational model and the characteristics of the common spaces that have been produced. We then show that the organisers behind this biennial have deliberately resisted engagement with the state and market, arguing that this is a necessity in Thailand's socio-political context. In the final section we will reflect on the consequences of this decision, discussing the sustainability of the biennial as well as its counter-hegemonic potential. Throughout, we stress the importance to study biennials and other commoning art practices not only as "art" events, but to instead place these events in the world, and to broaden the scope of analysis beyond contemporary art and its institutions.

\section{Contemporary Art in Thailand}

The biennial is one of the prime platforms through which people encounter contemporary art today (Green \& Gardner, 2016). Applauded as sites of experimentation (Basualdo, 2003), they are criticised for their complicity to the interests of states and corporations as well. However, next to state-funded and corporate-funded biennials, there are "other" biennials-like the Bangkok Biennial-that result from common-oriented art organising (Oren, 2014). While these various organisational models certainly influence the potential role of biennials, at the same time the specific characteristics of the societies within which they are organised are crucial for their form, role, and effects as well. We will therefore first discuss the characteristics of the Thai art system, and the context within which this functions (see also Teh, 2017, 2018; van Meeteren \& Wissink, 2019, 2020).

As even the most cursory observer will know, the past decades have seen recurrent street occupations, bloody clearances, and military coups in Thailand, resulting from radically opposing views of the Thai nation (Chachavalpongpun, 2014; Ferrara, 2015; Montesano et al., 2012). The dominant view-or, to speak with Gramsci, the hegemonic view-centres on three pillars: a nation built upon an imagined, uniform Thai identity based on ethnolinguistic homogeneity and so-called "Thainess" (Connors, 2005); a Buddhist religion; and a quasi-divine king, protected by strict lèse-majesté laws (Isager \& Ivarsson, 2010). The nation is presented as having a distinctly graded hierarchy with khon di ("good people") who aspire to be siwilai or "civilised" (Winichakul, 2000) at the top, and with Bangkok as its Sino-Thai centre, overseeing peripheries like the "Laotian" Northeast and "Malay" South. In this view, it is 
the task of the state-heavily leaning on the bureaucracy, monarchy, and army - to educate people and defend this unity against internal and external threats (Baker \& Phongpaichit, 2017, pp. 282-284).

Over the past decades, this hegemony has been challenged from two sides. On the one hand, with a switch to export-oriented production, economic conglomerates gained rapid influence and started to push domestic consumption (Phongpaichit \& Baker, 1998; Suehiro, 1992). They did not challenge the core ideas of national unity, religion, and monarchy, but did gain considerable influence on the functioning of the state (Baker \& Phongpaichit, 2017). On the other hand, and more fundamentally, the hegemony has been challenged by an egalitarian popular nationalism that situates sovereignty in the people rather than the palace. Embracing the nation's diversity, in this view the state should improve the well-being of all, and diminish the enormous political and economic inequalities (Baker \& Phongpaichit, 2017, pp. 282-284).

Art practices in Thailand operate within this context of hegemonic struggle (van Meeteren \& Wissink, 2020). Since the 1930s, the state perceived modern art as a means to mould public culture in the "right" way and to educate citizens (Teh, 2017). It developed institutions like Silpakorn University, national exhibitions, and national artists that were granted a monopoly on the signification and expression of Thai culture. The engagement of the state with contemporary art has been late, effectively only starting with the establishment of the Office of Contemporary Art and Culture (OCAC) within the Ministry of Culture in 2002 under the directorship of established curator Apinan Poshyananda. This founding director had already left the OCAC for some time when this office finally executed his long-held ambition to organise a biennial, resulting in the 2018 Thailand Biennale. In many ways, the Thailand Biennale was meant as an extension of the view that art should serve particular images of the nation, and it is therefore not surprising that it was mired by heavy-handed interferences in curatorial decision-making (van Meeteren \& Wissink, 2020).

The engagement of the Thai corporate world with contemporary art stemmed from the discovery of its potential for stimulating consumption. This coincided with the emergence of a new generation of contemporary art visitors, for whom consumerist imaginations of the "good life" are aspirational. The Bangkok Art Biennale is an exponent of this consumption-centred vision of art. It was inaugurated in 2018 by Thaibev as a means to add value to-or in the words of Boltanski and Esquerre (2020): to enrich-shopping malls and real estate owned by the company and its strategic corporate partners. In the hands of its artistic director Apinan Poshyananda-who, as we mentioned, had transitioned from the OCAC to the much more "efficient" market sector-the Bangkok Art Biennale aims to be an explicit counterpoint to the art of the state (Poshyananda, 2021).
The art on show also included various so-called "critical works," honed in on by reviewers in newspapers and art publications. However, underlining Mouffe's (2013) argument that critical gestures in the "advertisement domain" are easily appropriated and neutralised, a curatorial strategy of "total curation" has guaranteed that these critical works did not lead to serious discussion or engagement (van Meeteren \& Wissink, 2020).

The alternative art scene that started to develop in the 1980s was earlier in its engagement with contemporary art (Teh, 2018; van Meeteren \& Wissink, 2020). Newly instituted art schools-at Chiang Mai University and elsewhere-and study periods abroad brought students in conversation with alternatives to the state's views of art. New art spaces including the Ruang Pong Art Community in the 1980s, and Concrete House, Project 304, and About Studio/About Café a decade later, provided platforms that supported new artist networks (Teh, 2018). Art was thus increasingly wrested free from control by the "Silpakorn system"the system of state-centred institutions with Silpakorn University at its core that for long had exercised an iron grip on all facets of Thai art practices (see Teh, 2017; van Meeteren \& Wissink, 2020). These developments also supported the initiation of artist-led perennial events like Chiang Mai Social Installation (Teh, 2018), Womanifesto (Nair, 2019), Asiatopia, and the Bangkok Experimental Film Festival. Together, these artist-led activities created spaces that supported imaginations of another Thailand. The Bangkok Biennial aligns with this third view of art.

\section{The State, the Market, and the Common}

With a direct link between different types of art events, practices and spaces, and different visions of the relationship between state and society, the analysis of art practices in Thailand has an undeniably political dimension. The literature on the urban common provides a useful conceptual lens for analysing this fragmentation of the Thai art field. After all, a considerable part of this literature similarly presents commoning as a third way of social organising next to the state and market (e.g., De Angelis, 2017; Stavrides, 2016; Volont, 2020). In this view, the common is a means to "reassert participatory control over the urban commonwealth" vis-á-vis the state and market (Volont \& Smets, 2021). In the case of the Bangkok Biennial, this means resistance to control over contemporary art by creating and supporting alternative practices and infrastructures. The art organisers involved with the Bangkok Biennial emerge as commoners, who facilitate the addition of common spaces to the art landscape, through what are called biennial pavilions. These commoners thereby try to counter the appropriation of art by the state and corporations, and to broaden the public sphere by introducing spaces for imagining "different" ways of being and living. This supports the transformation of contemporary art from 
an advertisement domain of consensual soft power in which critical gestures are quickly appropriated and neutralised, into a core battlefield of explicit agonistic political disagreement (Mouffe, 2013).

While a small but growing number of publications have started to analyse Thailand through the concept of the common (e.g., Chaitawat et al., 2021; Shelby, 2021), the applicability of this framework has not yet been conceptualised well. In particular, for the analysis of art practices in Thailand we want to place two footnotes. First, the relationship between art and the common is complex, and its history still needs to be written. To mention just one obvious issue, state involvement with art in itself does not have to be problematic, provided that it functions through institutional arrangements that can guarantee relative independence to art organisers and their spaces. However, in Thailand state involvement has never really aimed at developing independent art practices. A discussion of art practices in terms of the common will therefore have to be a situated discussion, which is one of the reasons why we started our discussion with an analysis of the Thai art field.

Second, and related to this, as anybody familiar with this literature knows all too well, the writing on the common consists of various strands that each have their own assumptions and critical potential (e.g., Dardot \& Laval, 2019; Volont, 2020). In the words of Berlant (2016, p. 397), "the commons is incoherent, like all powerful concepts." We position our perspective of the common within one of those strands: the critical tradition that highlights the potential of this concept for counterhegemonic agency. However, with our last footnote in mind, we aim to broaden this perspective. After all, following authors like Hardt and Negri (2009), De Angelis (2017), and Dardot and Laval (2019), a considerable part of this critical literature discusses the common mainly in relation to neoliberal economic practices. As a case in point, Dardot and Laval (2019, p. 125) state: "For us, the common is the philosophical principle that makes it possible to conceive of a future beyond neoliberalism." While we obviously acknowledge the role of neoliberal practices in domination, at the same time we stress that other forms of domination-for instance, in relation to the Thai autocratic state and related views of national identity, as well as issues of race, gender, and ageneed attention as well. We do so from the shared conviction that while there are clear intersections between class and difference, a focus on class alone will be insufficient for an adequate analysis, or for meaningful action for that matter (e.g., Fraser, 2014). Again, this means that an analysis of art practices through the lens of the commons should be a situated analysis, in which the particular intersections are highlighted of class and difference that are at play in forms of domination which counter-hegemonic practices seek to resist-in our case in Thailand.

With these footnotes firmly in mind, we set out to analyse the Bangkok Biennial through the lens of the common. Following the discussion of Volont and Smets (2022) in the introduction to this thematic issue, we will especially focus on the relationships-if any-that organisers of the Bangkok Biennial have established with the state and corporations. As these authors have pointed out (Volont \& Smets, 2021), the long-term viability of common spaces might necessitate the support of the state or market. However, they also acknowledge that these relations might result in the appropriation of common practices. In social theory, this question of engagement with the state and market is not a neutral one. In view of the risk of appropriation, Virno (2004) for instance argues that the best way for the "multitude" out of the current "disciplinary regime" is withdrawal or "exit," in the hope that this will eventually establish an "absolute democracy." Hardt and Negri (2009) advocate a similar "exodus" strategy.

Mouffe (2013) disagrees. She argues that an effective counter-hegemonic offensive to the capitalist order has to be organised within a variety of practices in a multiplicity of spaces, including the art practices and institutions of the state and market, so as to prevent that common practices will only create an "extra" outside of the capitalist world. However, in her recent writing Mouffe (2018, pp. 91-92) has delimited this approach of "agonistic engagement" to certain circumstances-the institutions of pluralist democracy-that do not exist in Thailand. In such other situations, according to Mouffe, antagonism is the only viable approach. Or, as she argued in a discussion during an inappropriate BOOK CLUB meeting that we organised in Bangkok in the spring of 2021 (www.facebook.com/inappropriateBOOKCLUB), "a dictator is always an enemy that needs to be removed." With our observations of the need for a situated analysis firmly in mind, we explore which form the common art practices of the Bangkok Biennial take; we wonder how the commoners behind this biennial have navigated the needs and challenges of connections with the state and market; and we question what this means for the sustainability and counter-hegemonic potential of this event.

\section{Researching the Bangkok Biennial: Some Remarks on Methods}

In this article we foreground the effects of the choices of the Bangkok Biennial organisers regarding the mode of organising this biennial, and regarding relations with the state and corporations for both its sustainability and counter-hegemonic potential. In particular, on the basis of an exploratory analysis, we aim to reach a speculative understanding of possible linkages between these "strategies" of the Bangkok Biennial organisers and the effects that these might have had. We base this exploratory analysis on three types of sources. First, as organisers of one of the 2018 Bangkok Biennial pavilions, we were cast in a process of participant observation. This pavilion-coming soon - เร็ว ๆ นี้consisted of a video installation in a small room at 
the back of our house, presenting eleven Thai and Hong Kong artists discussing their experiences with, and expectations of, the arrival of the "international art world" (https://www.comingsoonbkk.com). Visitors were invited to watch the videos and discuss their experiences with and opinions of the effects of the entrance of international art world actors into their art ecosystems. As pavilion organisers, we gained first-hand experience with the organisation of the Bangkok Biennial, with the choices and requirements involved, and with the interaction between biennial initiators and pavilion organisers.

Second, we visited about thirty of the seventy pavilions that were organised in the context of the 2018 Bangkok Biennial. During these pavilion visits we observed the physical pavilion spaces, the presentation and engagement formats employed, and the social interactions that took place. We also talked with the pavilion organisers about the ideas behind their pavilions, the rationale for their Bangkok Biennial participation, the funding and practical organisation of their pavilion, and the role of art in society in general, and in Thailand in particular. In about half of these cases we have met up again and talked further with pavilion organisers about their ideas-often when visiting other Bangkok Biennial pavilions.

In addition to these informal conversations, we have also conducted about twenty hour-long structured interviews with Bangkok Biennial initiators, pavilion organisers, and with "outsiders" that could reflect on the Bangkok Biennial vis-à-vis other biennials in Thailand, and the Thai art world in general. During these interviews we discussed the aims and strategies of the biennial and pavilion organ- isers, the reasons for participating in the biennial, practical issues including funding and production, challenges relating to the sustainability of the biennial, the effects of this biennial for the Thai art world, and the political protests that erupted in Thailand in 2019. Arranging these interviews turned out to be easy, as they were either based on personal contacts or introductions by people that we know. The first batch of ten interviews were conducted face-to-face in Bangkok, either at our home, at pavilions, or in studio spaces. Due to the Covid-19 pandemic we have had to conduct our second batch of interviews online. We have transcribed the interviews and then analysed them following the structure of this article. The quotes that are woven into our analysis on the coming pages are taken from these twenty interviews.

\section{The Bangkok Biennial and Its Pavilions: Strategies and Common Spaces}

As we observed at the start of this article, the Bangkok Biennial is an artist-initiated, self-organised, and collective bottom-up event. So far, it has been organised twice, with the first edition taking place over a three-month period in the summer of 2018. Due to the emergence of Covid-19, the 2020 event was postponed and eventually unfolded as three shorter "episodes" between October 2020 and October 2021. According to the initiators, the Bangkok Biennial is meant to be "a level platform, a participatory framework and open-access" (Bangkok Biennial, 2018). It thereby aims to challenge mechanisms of gatekeeping and the top-down hierarchy in art events in Thailand.

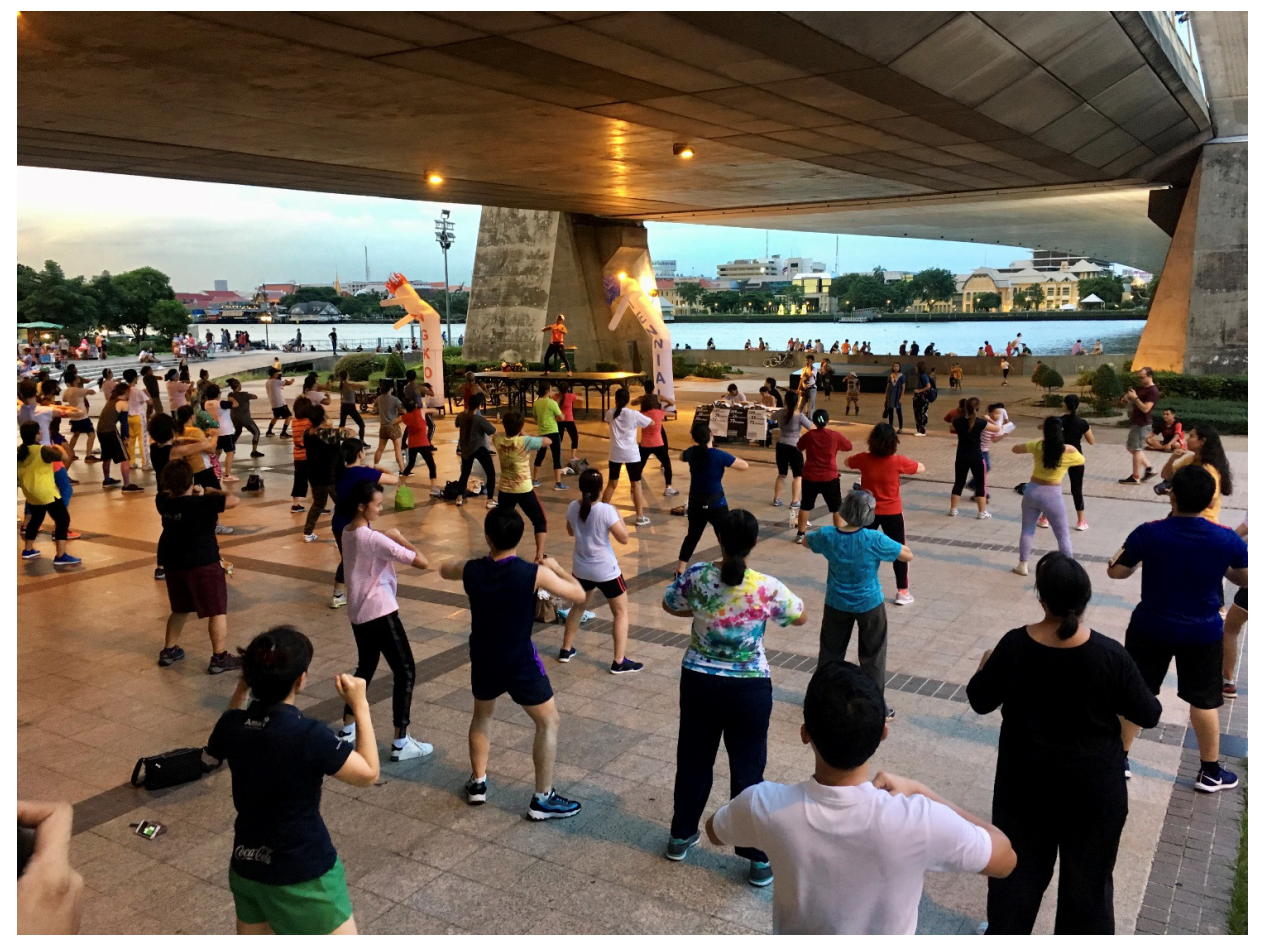

Figure 1. Bangkok Biennial opening ceremony during the daily 6 PM public aerobic session, under the Rama VIII bridge in Bangkok (July 2018). Photo by the authors. 
The Bangkok Biennial initiators have made various decisions to ascertain that the Biennial would live up to this ideal. First, the biennial does not have a central organising authority, no central budget, no theme, and no central curator. There is no central exhibition, nor are there other "central" facilities. Instead, the biennial initiators acted as facilitators and insisted upon anonymity in the run-up to the first edition, so that the biennial would not be "defined by the various people initially involved" (Bangkok Biennial, 2018). Secondly, and related to this, the core of the Bangkok Biennial is formed by a collection of decentralised initiatives, called "pavilions." The "commoners" that create these pavilions are themselves responsible for the form, content and funding of their programme. In 2018 this resulted in some seventy pavilions. The third characteristic of the event, radical openness, was achieved by doing away with selection criteria: anyone could join and register a pavilion through an open online registration platform. As we will see, there were restrictions regarding the participation of commercial parties, but apart from this, there was no form of selection or control.

As a result of these choices, pavilions have been a lot of different things. In the first edition, pavilions were located in parks, temple grounds, private homes, empty plots of land, and indoor markets, as well as in more conventional art spaces and galleries (see Figure 2). Furthermore, they were located in Bangkok and beyond, with pavilions in the north-eastern city of Khon Kaen and in Pattani in the "Deep South" that aimed at resisting the control by Thailand's centre and Bangkok in particular (see Figures 3 and 4). Pavilions were flexible in time as well: Some pavilions were one-night affairs, others remained open and active for several weeks or for the full duration of the biennial. The communication about the pavilion's activities was organised through a crowdsourced online wiki-type environment, as well as through the Bangkok Biennial page on Facebook-which, while under fire globally, is still widely used in Thailand for lack of an alternative. With these characteristics, the Bangkok Biennial is a clear example of what Stavrides $(2016$, p. 50) calls "expanding commoning," which "always invites different groups or individuals to become co-producers of a common world-in-the-making."

These decisions have led to a biennial that lacked what Gardner (2019) has called the "spectacle time" of the opening event. The state-organised Thailand Biennale and corporate Bangkok Art Biennale used their opening events to showcase their vision of the "right" society or "good life" respectively to a select group of honorary spectators-be they state dignitaries, corporate sponsors, or hi-so visitors. Instead, for its opening, the Bangkok Biennial circulated an invitation to participate in an outdoors aerobics session-a 6 PM activity happening all over Thailand (see Figure 1). Hot, sweaty, loud, accessible to everyone, and as such indistinguishable from the messy daily life in the city, it represented the epitome of inconvenience for people that aspire

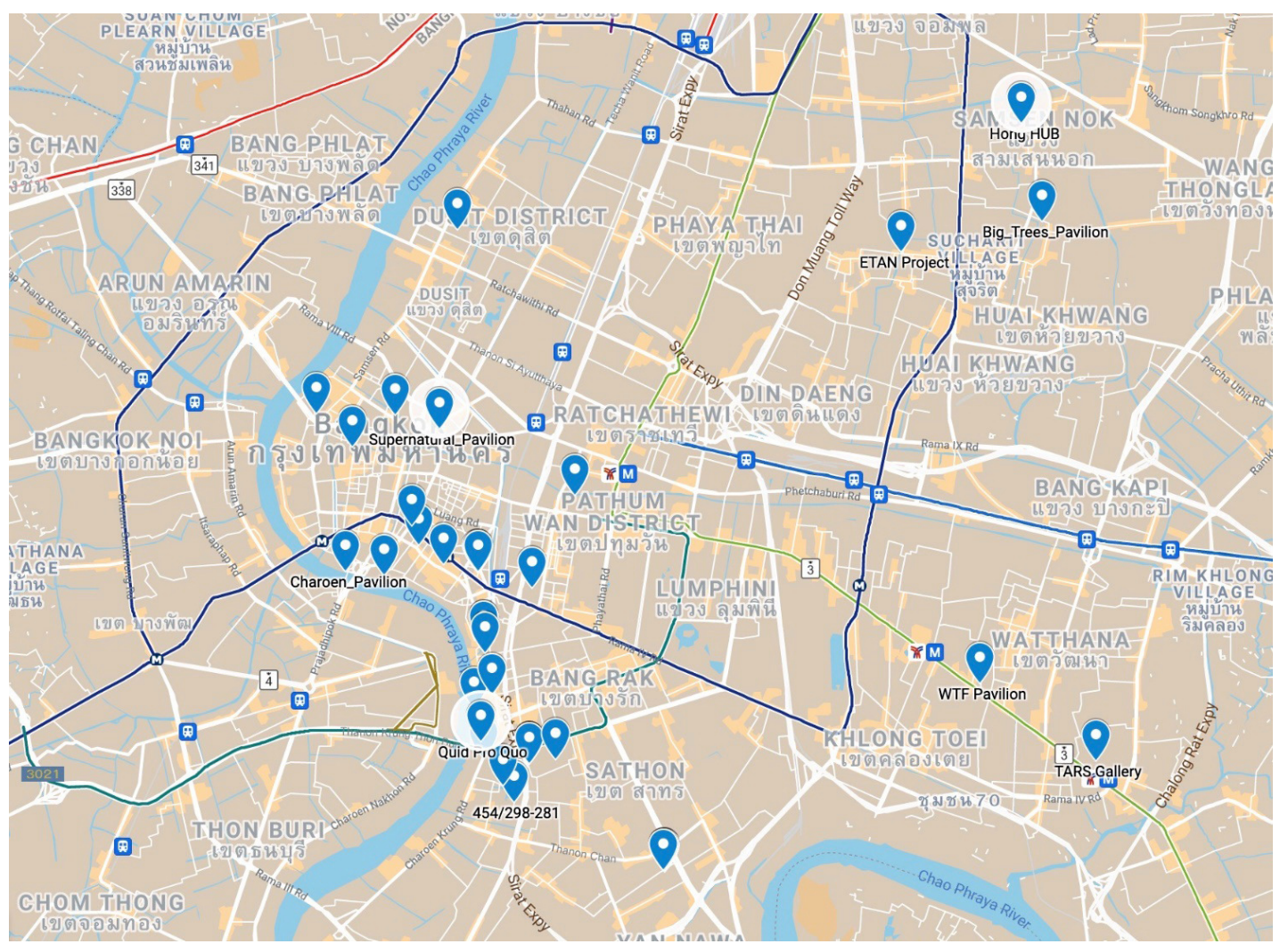

Figure 2. Overview of the location of Bangkok Biennial 2018 pavilions in central Bangkok, with three discussed pavilions highlighted. 


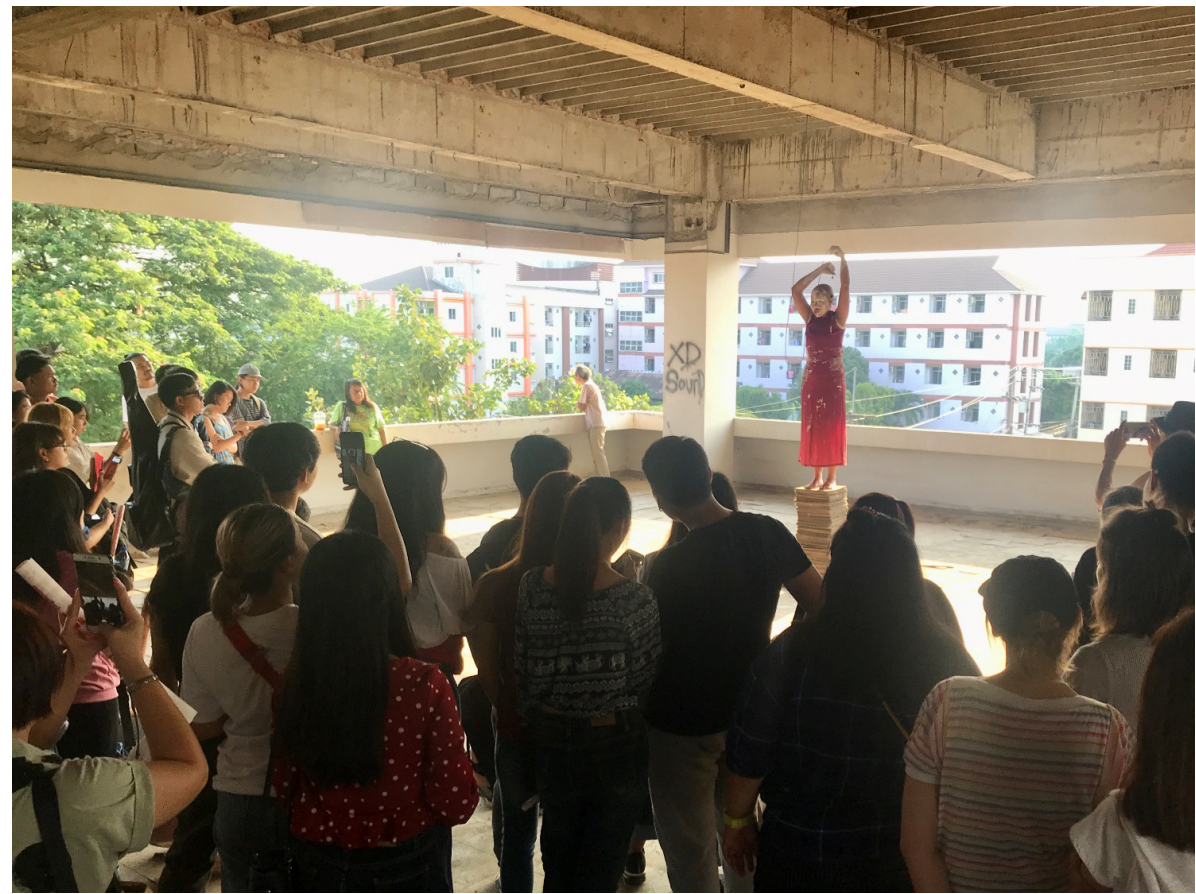

Figure 3. The Monument in the Motherland performance by Wilawan Wiangthong at Khon Kaen Manifesto in Khon Kaen (October 2018). Photo by the authors.

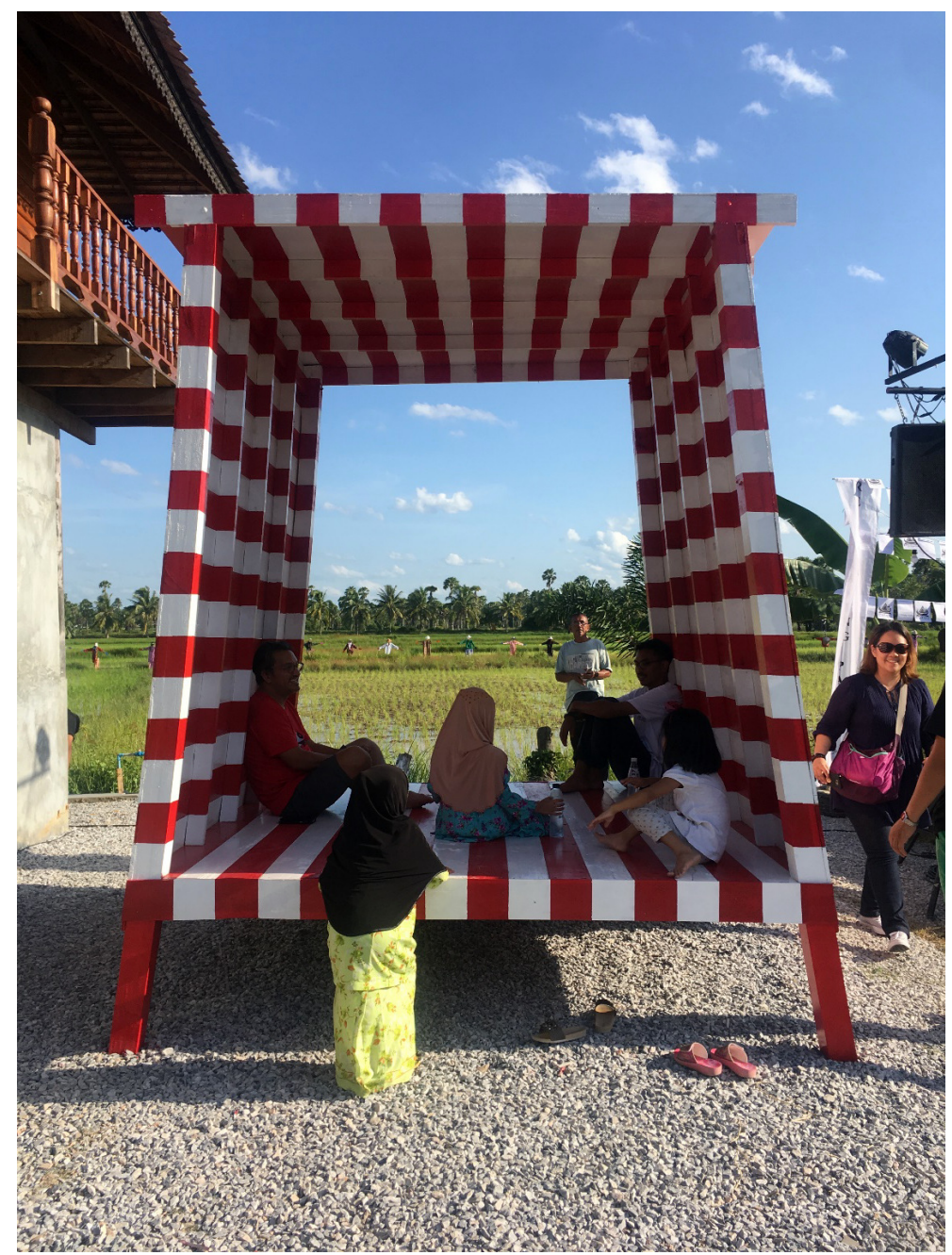

Figure 4. Patani Playhouse by Firhana Almuddin, made for RE/FORM/ING PATANI at Patani Artspace in Pattani (August 2018). Photo by the authors. 
to live the "good life," foreshadowing a biennial that is not easy to consume. Throughout the Bangkok Biennial, the pavilion's prime audience consisted of a growing local community of participants whom-supported by the biennial's temporal strategy-over a three-month period visited many pavilions that often approached them as contributors and co-creators instead of passive spectators. Artworks were often the pretext for encounters, and not necessarily the main point (cf. Teh, 2018). Slow social engagement replaced quick consumerist visits, reminding us of Berlant's (2016, p. 395) observation that the "better power of the commons is to point to the difficulty of convening a world conjointly, although it is inconvenient and hard, and to offer incitements to imagining a liveable provisional life."

The biennial's pavilions have created a temporary network of pockets of resistance, coming to the surface here and there. The overwhelming majority of these pavilions were connected to their location through engagements that predated the biennial or forged links with people or groups with an attachment to that place. The biennial functioned as its own ecosystem, with spinoffs, interactions, and collaborations between pavilions that didn't necessarily pass through a centre. As such the biennial became more than the sum of its parts. That said, a closer look at three of those parts can help to further illustrate the character of this biennial.

Supernatural Pavilion was co-produced by Japanese theatre maker Chiharu Shinoda (or "Shin") and the E-Lerng Group in the Wat Khae Nang Loeng community. This tight-knit community of some 200 households in the vicinity of Sunthorn Thammathan temple (colloquially known as Wat Khae Nang Loeng) is located in Bangkok's old town and faces many of its prob- lems, including poverty, drug abuse and eviction threats. Spending about ten years working and living in Thailand, Shin had started to collaborate regularly with the E-Lerng Group in 2010, doing workshops with children amongst other things. With a large and varied interest in the supernatural in Thai popular culture, the community had suggested to Shin to organise an activity based on the many ghost stories of the area. As Shin herself recollects, "the first idea did not come from me; it came from the community.... think that the community likes how I work with community people." However, with funding hard to find, the plan went on the backburner. It was revived for the Bangkok Biennial with help of artists providing a logo, stickers, a zine, and riso-printed posters that were sold to raise funds (see Figure 5). This resulted in a three-part Supernatural Pavilion spread out over a month. The first part, the performance $5 \times 5$ Legged Stool, was based on the dance score Five Legged Stool (1962) by Ann Halprin. Openly accessible, it was performed on the neighbourhood temple grounds. In the second part, Tiger, Tiger, Japanese dancer and actionist Aokid and local drum-player Khruu Pin led residents and visitors on a neighbourhood parade past spots known for supernatural activity (see Figure 6). The third part, Kannagara/ZOO, consisted of a VR installation in two locations. Supernatural Pavilion returned for the second edition of the Bangkok Biennial-this time in an online format in view of Covid-19-aimed at supporting the community during the pandemic.

Hong HUB is a residency programme in a house in the quiet, residential Sutthisan/Huai Khwang area. It was established by Thai exhibition maker Ekarat Tosomboon, who has been based in France for over 10 years but grew up in this neighbourhood and still has strong ties here.

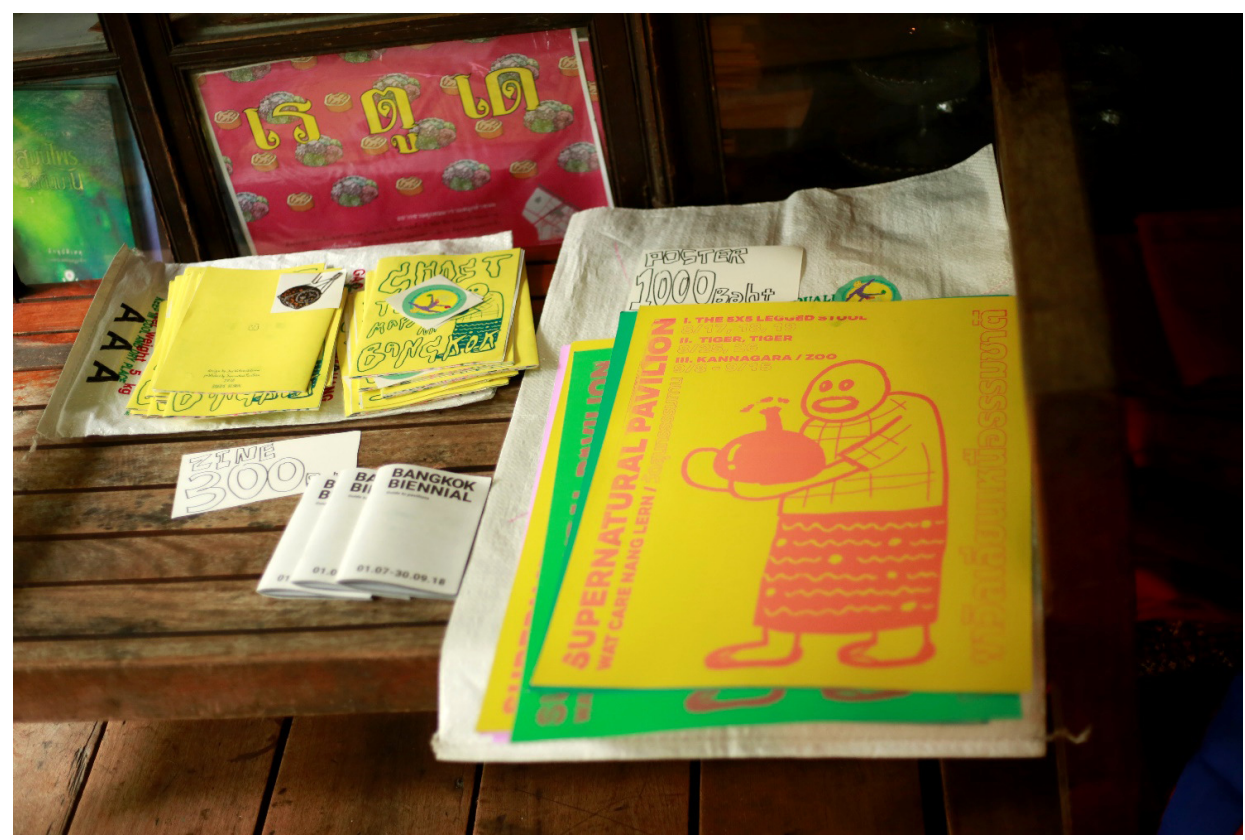

Figure 5. Zine and poster of Supernatural Pavilion at Baan Silapa (September 2018). Photo by TRMN, courtesy of Chiharu Shinoda. 


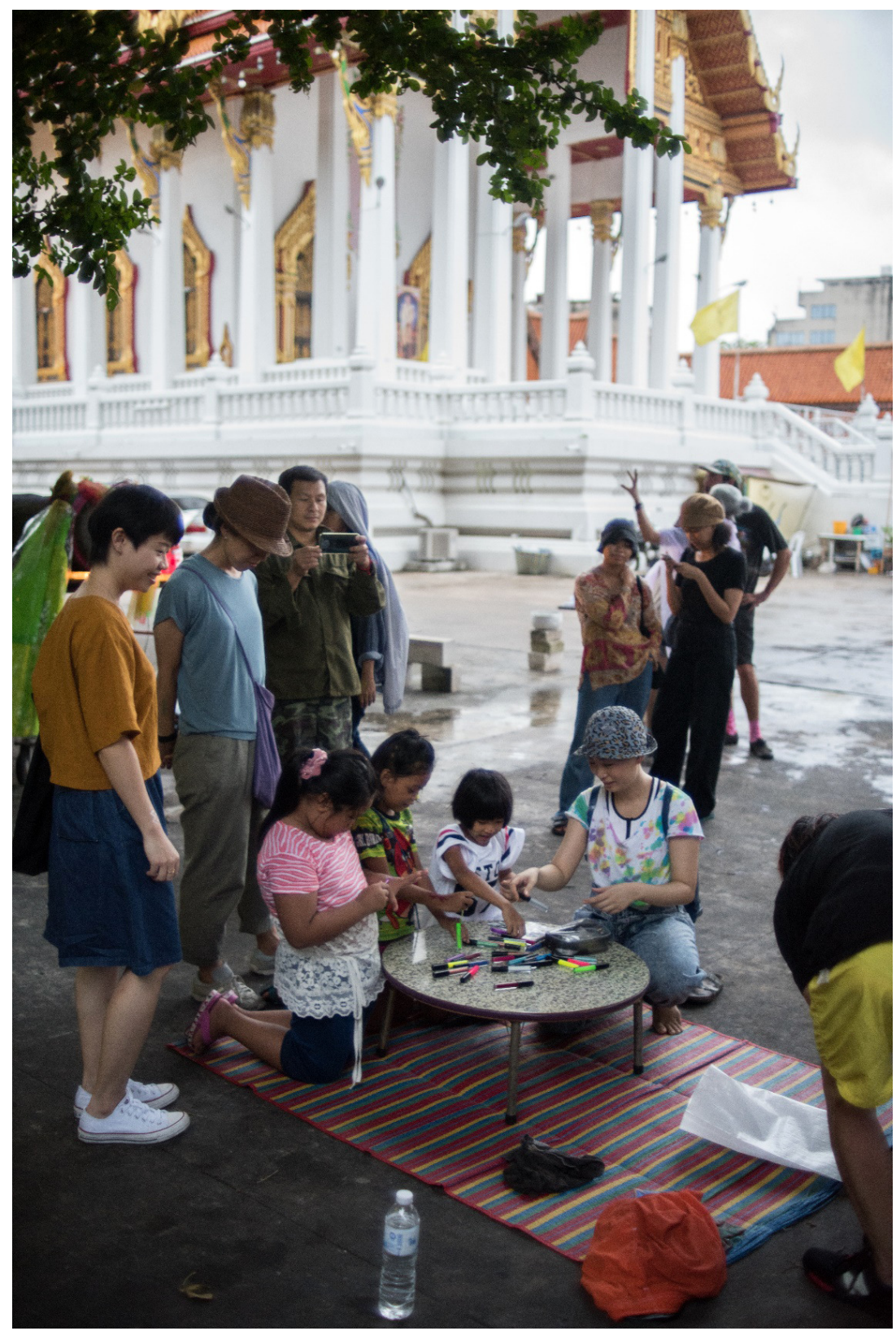

Figure 6. Tiger, Tiger parade and performance at Soonthorn Thammathan temple (Wat Khae Nang Loeng) in Nang Loeng, Bangkok (August 2018). Photo courtesy of Bangkok Biennial.

In Ekarat's perception, contemporary art-related events have now exploded all over Bangkok, but they mainly target a consumer class and are not relevant for people in the neighbourhoods where they happen: "For me, doing that in my own street, it was not possible....The idea [of the pavilion] was to do something that has some meaning for the people around this area." The resulting Hong HUB pavilion-developed with French curator Maëlys Moreau-was funded by the Institut Français, the municipality of Rennes and the Jeunes à Travers le Monde youth organisation. It combined various elements including a collaboration with the French Init Collectif and alternative art space Speedy Grandma in Bangkok that centred on the exchange between artists in France and Thailand. Another part took place on a family-owned plot around the corner of Hong HUB. French artist Michaël Harpin, a participant in the residency programme, hung posters-a common sight in Thai neighbourhoods-asking people to donate broken pots and other building materials (see Figure 7). With these materials, Harpin built a structure that functioned as a sculpture, a conversation starter, a resting place, and an outsized botanical vessel. The unusual activity in the July heat drew attention from the neighbourhood, with taxi drivers hanging around the plot, for instance, starting to explain to curious passers-by what was going on. The work was inaugurated in early August through a blessing ceremony performed by Buddhist monks and a lunch, guaranteeing that all neighbours felt welcome (see Figure 8). 


\section{COGITATIO}

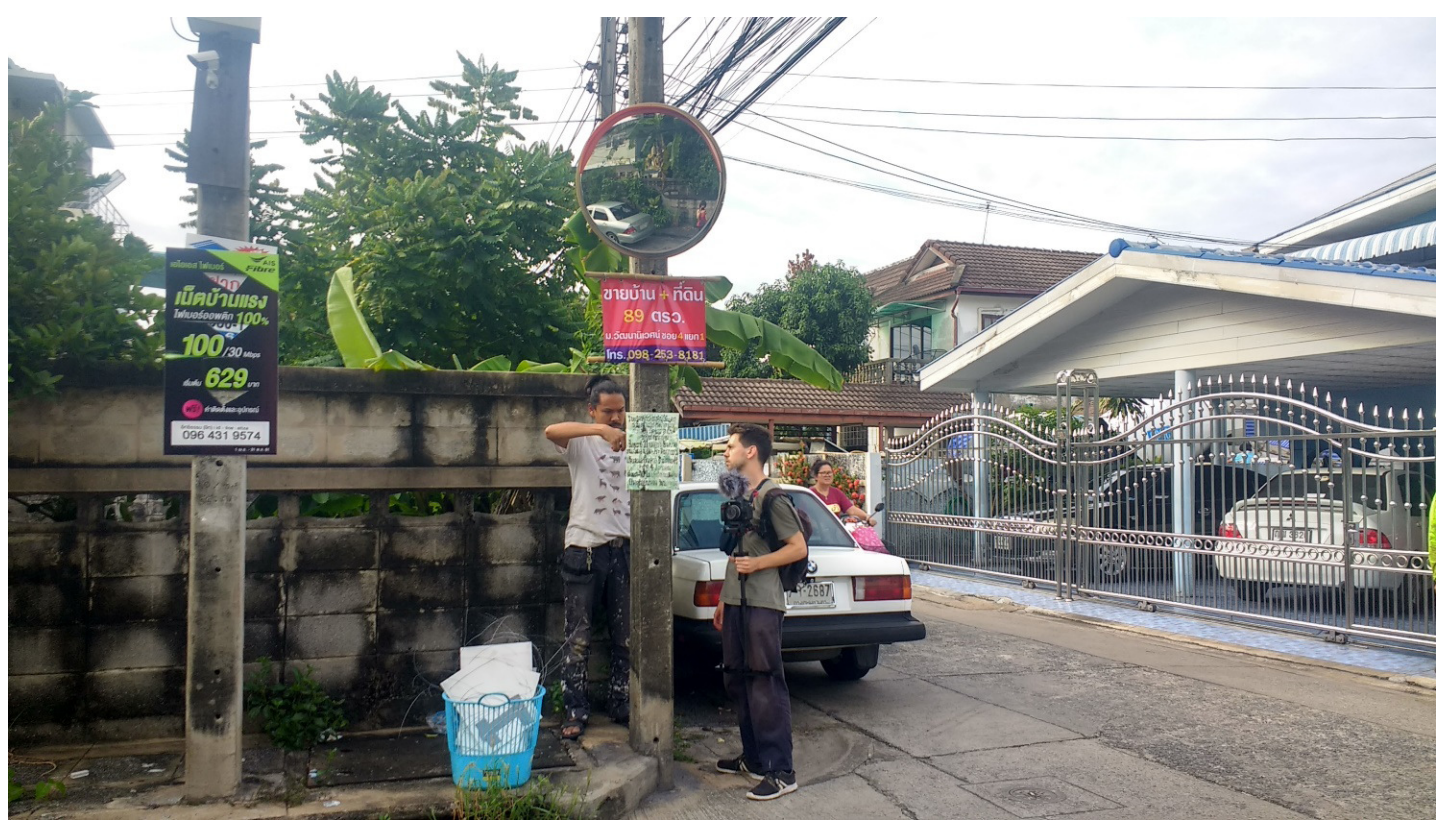

Figure 7. Ekarat Tosomboon and Michaël Harpin hanging posters requesting broken pots in the Hong HUB neighbourhood (July 2018). Photo courtesy of Hong HUB.

The Quid Pro Quo pavilion was organised by LIV_ID, a feminist collective consisting of Thai and American artists and organisers, aiming to create things outside gallery spaces, which they felt didn't happen much. When the open access Bangkok Biennial was announced, the collective was excited. The members were working or living in Bang Rak, a central riverside neighbourhood at the edge of the recently rebranded Charoen Krung Creative District. Bangrak Bazaar-an indoor market that the collective often visited-is a remnant of a not-so-smooth former Bangkok that does not agree with the new image of this district. According to one of the members, Elissa Rae Ecker, it was a natural fit for their pavilion: "If you actually take the time and look around, there is so much to see already.... It is big. We knew we could place things and they would get lost....We wanted things to kind of just become part of the daily market." Confused about their plans but equally intrigued, the owner of the market was soon on board. With funding from a Thai art patron, LIV ID contacted the Guerrilla Girls to ask permission to translate their Wealth and Power poster into Thai (see Figure 9). Next, they approached other fem-

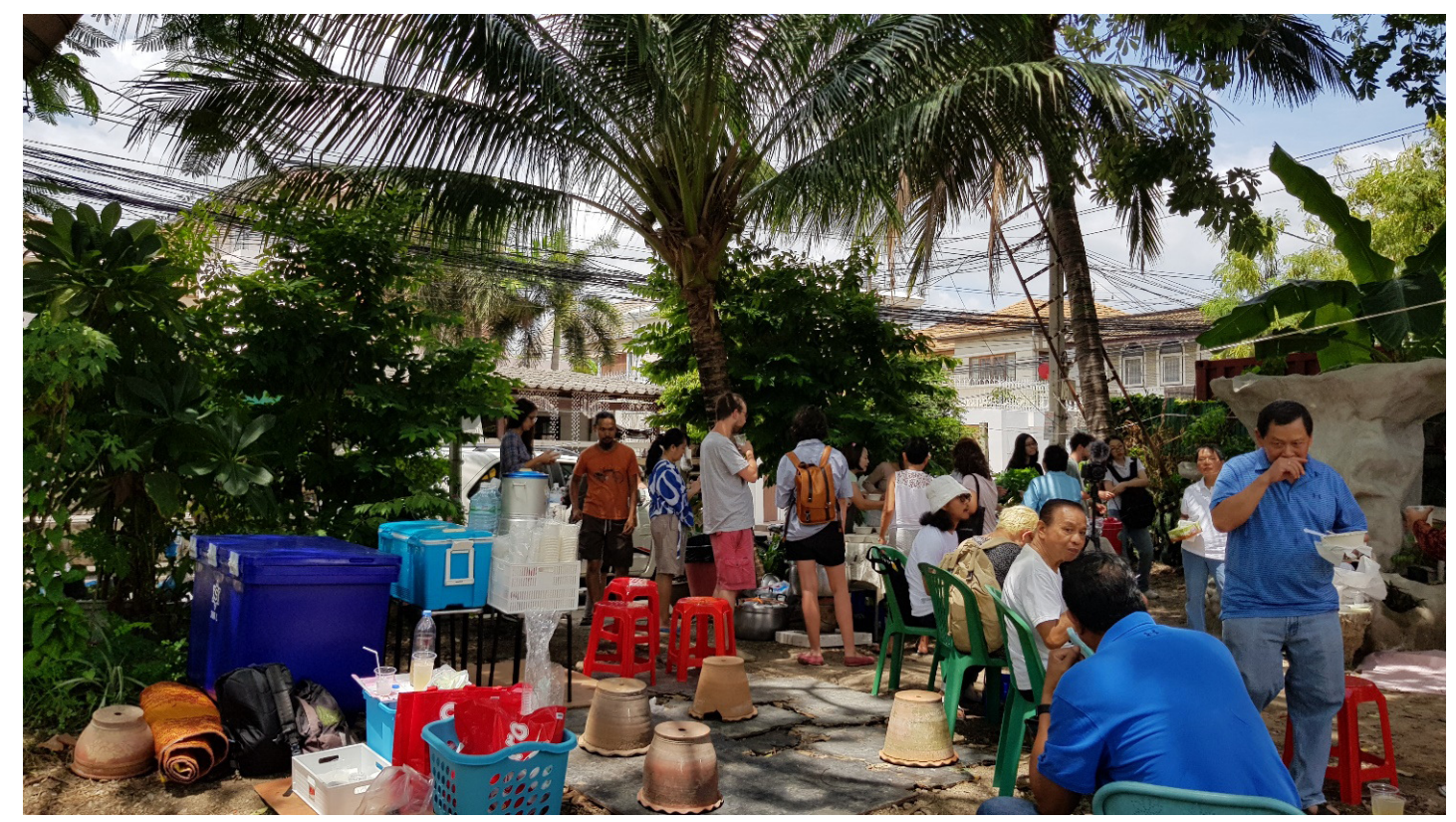

Figure 8. Lunch and ceremony inaugurating Michäel Harpin's sculpture, visible on the right (August 2018). Photo courtesy of Hong HUB. 


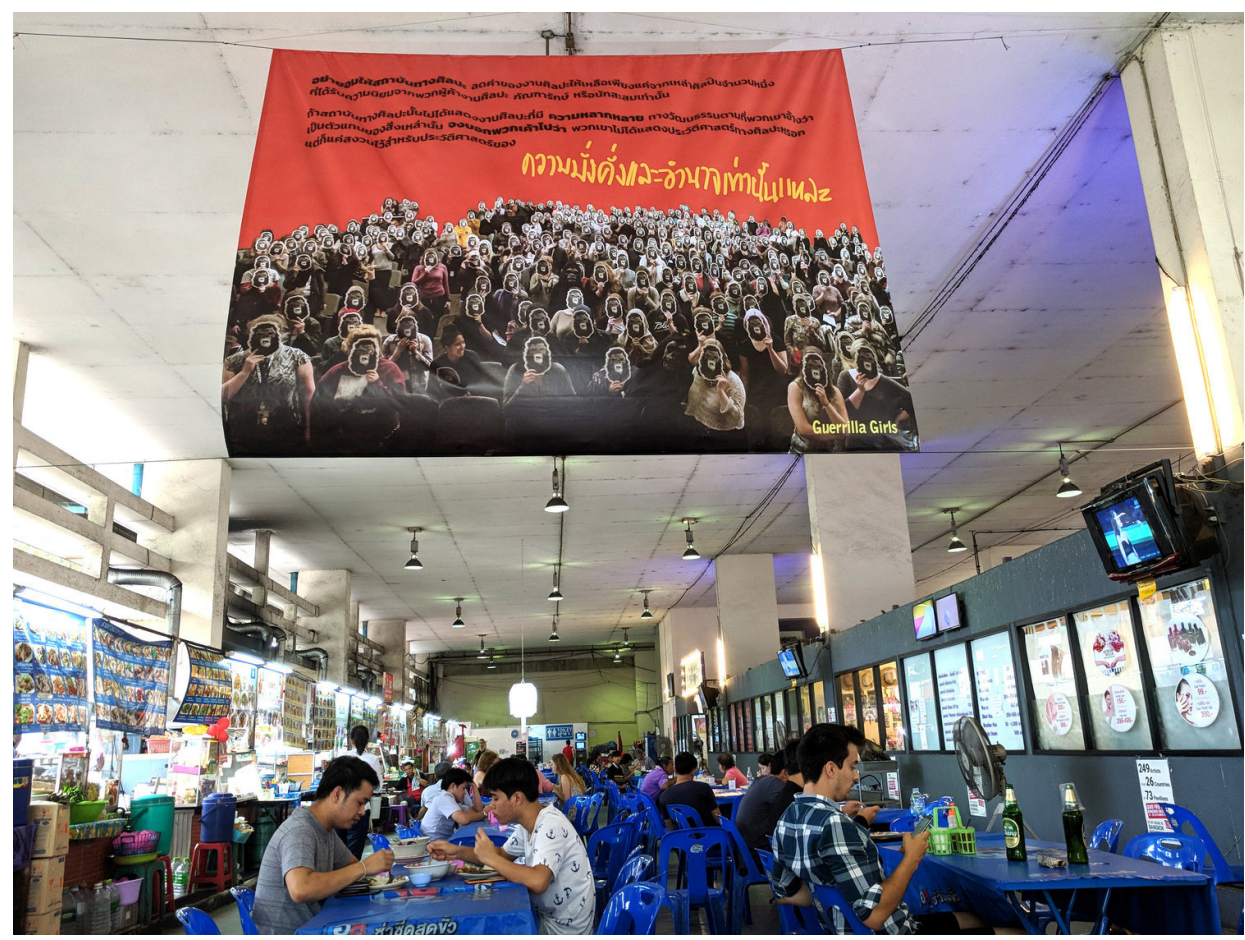

Figure 9. Wealth and Power by the Guerrilla Girls hanging in the food court at Bangrak Bazaar market (September 2018). Photo courtesy of LIV_ID.

inist artists and collectives to contribute as well (see Figure 10). In the process, the collective got to know the vendors well, and one tattoo artist for instance asked if he could be an artist in the pavilion. According to Elissa, the collective was enthusiastic: "Yeah, sure! So, we kept adding people onto our pavilion map, if they wanted to be an artist in our pavilion." The opening night of the month-long pavilion started with three all-female bands playing at indie music venue JAM. Afterwards, the art event crowd and unsuspecting market visitors alike were treated to a feast prepared by the vendors at the market's food court for which no one had to pay, illustrating the collective's agenda to siphon "art money" away and spread it around in new ways. LIV_ID was another organiser returning for the second Bangkok Biennial edition in 2021.

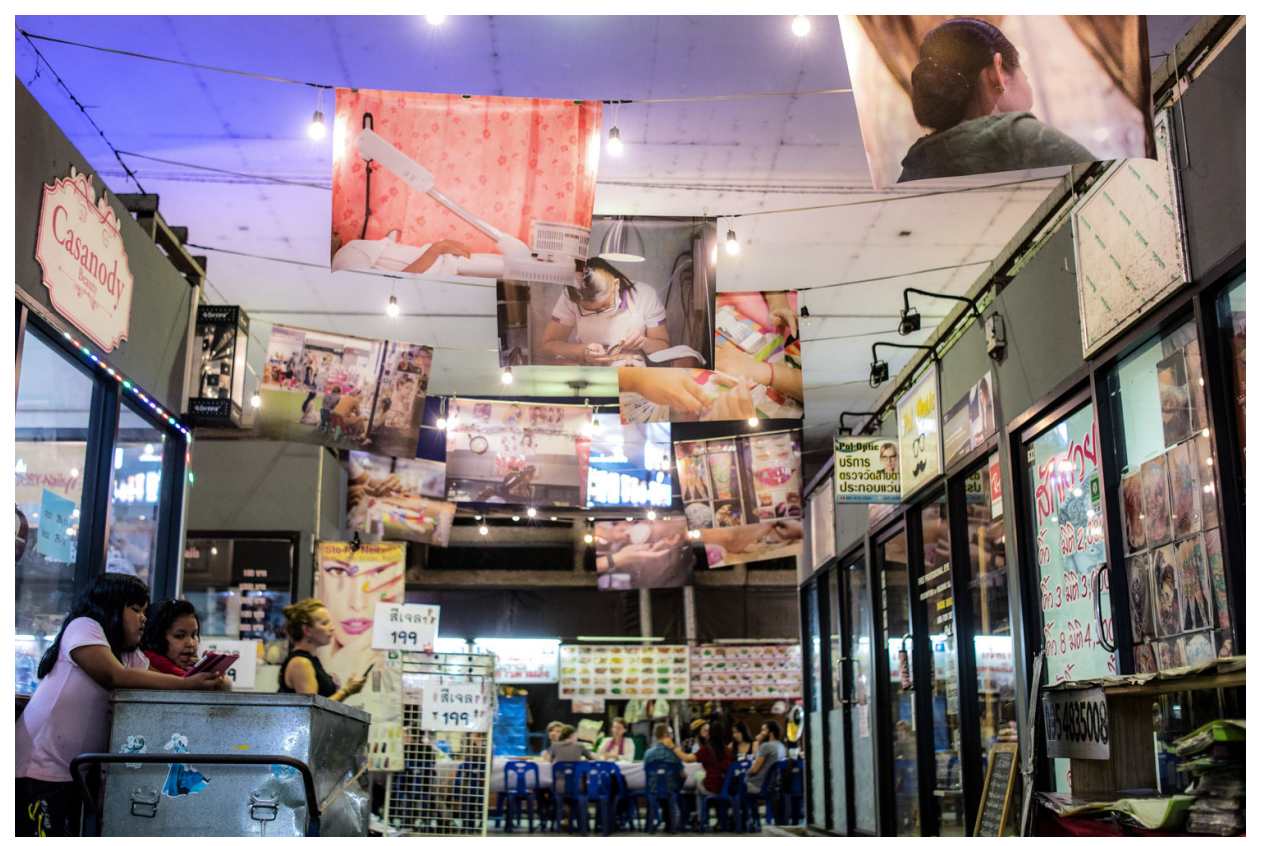

Figure 10. Bangrak Beauty by Sareena Sattapon, photos of workers and vendors in Bangrak Bazaar's beauty zone (September 2018). Photo courtesy of LIV_ID. 
These three pavilions illustrate that the Bangkok Biennial has worked as a spark, igniting people to organise things concurrently that might or might not have happened otherwise. It also enabled this organising by creating a context that helped with funding, inviting participant artists, and building an audience. The resulting diversity of pavilions had many characteristics in common. Mostly, pavilion organisers built on long engagements with places and communities. And often, pavilion visitors would be received by the art organisers and artists involved with those pavilions, who would have considerable time for exchanging ideas. Many of these organisers and artists would also visit each other's pavilions over the three-month period of the biennial. In their encounters, participating artists and art organisers would often display enormous enthusiasm and energy, and a strong sense of care as they had conceived everything themselves from start to finish. Most importantly, however, many organisers resisted the hierarchies at play inside and outside of art in Thailand, claiming their "right to the city." The strong commitment to this mission is also illustrated by the return of organisers for the second Bangkok Biennial. As such, for a limited period of time, the Bangkok Biennial has added common spaces as pockets of resistance to the "long-term" independent art spaces existing in Bangkok. Or, as one of the biennial organisers concludes:

The biennial is very visible and fast. It came up, it was exciting, it got a lot of media attention, and a lot of people were involved. So, it had more public outreach than a long-term, smaller-scale [independent art] space....So, [the Bangkok Biennial and existing independent art spaces] have different roles, [but they point] in a similar direction.

\section{The Necessity of an Antagonistic Approach}

This leaves the issue of connections with the state and market-which is a decision in its own right. Here we make a distinction between connections of the Bangkok Biennial with the state and market in general, and connections with art organisations of the state and market. Regarding the connections with the state and market in general we can be relatively short: the Bangkok Biennial team has consciously not engaged with either. There was no contact with the state at all, but the initiators were approached by various market parties that offered sponsorship in return for brand advertisement. However, as one of the initiators recollects:

The model that we wanted to set up was based on the fact that the pavilions deal with everything themselves. [Us accepting sponsorship would make] people question things. If I was considering organising a pavilion and...I read...that you must find your own funding....and then I see that there is sponsorship; then I think "where does that money go; why do
I have to find my own money if they get money from those people?"

Thus, the feeling was that accepting central sponsorship would undermine the organisational model of the biennial. In the end, the organisers decided not to accept any of the sponsorship offers. Instead, they negotiated free printing of guidebooks and posters from a friendly local printer and managed to sell two wind tubes used during the opening to a Thai collector to pay for the Bangkok Biennial app. When they realised that, for subsequent editions, they would need funding to develop the online platform, which could guarantee the sustainability of the event, they looked for this outside of Thailand.

For the individual pavilions, the picture is more diverse. Some pavilions-like PostScripts by Charoen Contemporaries that took place in a building owned by Thailand Post-had to interact with government agencies for permission. However, by and large, the story here was the same, and interactions with both state and market were kept to a minimum. In short, the initiators of the Bangkok Biennial have operated from an antagonistic stance, imagining state and market parties not as friendly opposition, but as enemies with whom they shouldn't engage. Or, in the words of Volont (2020), they have engaged in "oppositional commoning."

When looking at the relations with the state and market within the art system, things are a bit different. Generally, the art spaces involved with the Bangkok Biennial came from the field of independent organising discussed earlier. However, in their role as organisers of TalkTalkVilion-a discussion pavilion - the biennial initiators did approach the Bangkok Art \& Culture Centre, a municipally funded space, as well as the Jim Thompson Art Center, a privately funded art space linked to the Jim Thompson silk company. Eventually, TalkTalkVilion took place at the latter. The pavilion organisers had meant to instigate engagement with the organisers of the Bangkok Art Biennale and the Thailand Biennale. However, both of those biennials didn't send core representatives and the hotly anticipated debate never became a real conversation. According to one of the organisers, the Bangkok Art Biennale organisers and the OCAC "are probably not in the business of criticality. They don't want to be...the subject of criticism....Furthermore, within the OCAC there is a potential that they don't want to legitimise the BB by sending a high-level representative." So, here actually the Bangkok Art Biennale and Thailand Biennale organisers did not want to engage with the Bangkok Biennial.

How to understand and judge this antagonistic approach? Not everyone has looked upon this positively, and the emergence of several concurrent biennials was derided by various art professionals as "typically Thai." However, in our opinion, this overlooks the fundamental antagonistic nature of Thai politics. In a setting of hegemonic struggle, the decentralised open approach of the Bangkok Biennial is alien-and even a threat-to both state and market parties. After all, those are in the 
business of selling the "right" images of the Thai nation, either in relation to nation-religion-monarchy or in the form of the consumerist "good life." In such a setting, cooperation would certainly mean diluting the aims of radical decentralisation and openness; something that is further illustrated by the disinterest of the Bangkok Art Biennale and the Thailand Biennale in the Bangkok Biennial, or for that matter in each other. This illustrates as we have stressed in our footnotes to the literature on the common that context is crucial. Speaking from India, Kapur (2018, p. 88) has argued for an antagonistic approach there, because "confront[ing]...hostile conditions in a grossly unequal world through the model of agonism seems difficult." Speaking from Thailand, and considering the fundamental non-democratic nature of the Thai state, we conclude that here an antagonistic strategy has been a necessity for the commoners behind the Bangkok Biennial as well.

\section{Beyond Antagonism? After the Bangkok Biennial}

While resistance to engagements with the state and market might be understandable-and even necessary-in the Thai context, at the same time, this brings specific challenges. As Volont and Smets (2021) have pointed out, without support from the state and market, the sustainability of the Bangkok Biennial could easily come under pressure. This is very understandable when realising that the full brunt of independent organising rests on the shoulders of a few with no-or limited-material returns, in economic settings that are increasingly precarious. Or, as one Bangkok Biennial organiser shared with us:

The first time that you do it you are running on adrenaline. It's pure energy. And then you are fucking exhausted afterwards. And then, when you think that you will do the whole process again, it is pretty daunting, because the adrenaline is not there anymore.

It is not surprising, therefore, that while independent initiatives might exist shorter or longer, as Oren (2014) observes, after a few iterations they generally either disintegrate or institutionalise. An alternative could be to pass on organisational responsibilities to others, but that is not easy either, as "even to find someone is already a job." To add insult to injury, with time and money seriously constricted, archiving, documentation, and theorisation are especially limited, and without serious scholarly work, often the traces of works, spaces, practices, and events disappear over time. It is not surprising, therefore, that one art organiser from the Philippines told us that, for them, "one major critique [of independent art organising] would be the lack of a sustained dialogue due to lack of documentation....They are talking about the same things [every time again], almost the same issues."

There is a second issue relating to the sustainability of the Bangkok Biennial, which centres on the risk of appropriation. With its strategy of radical openness, over time the commoning character of the Bangkok Biennial could come under pressure. What, for instance, if commercial galleries aggressively start using this event for their commercial purposes? The Bangkok Biennial would certainly not be the first common initiative to be appropriated in this way, as experiences with the invasion of a common event like Burning Man by commercial enterprises, for instance, illustrate (Spencer, 2015). Thus, even when consciously deciding against engagement with the state or market, without any access control, the common character of this event might still be at risk. In this light it is not surprising that the Bangkok Biennial works with a guideline restricting commercial pavilions. As one initiator explains, "in the first edition there were a number of pavilions which we didn't accept because of that rule." The messiness, "unprofessionalism," as well as the lack of smoothness of the Bangkok Biennial-all symbolised by the "discomfort" of its opening event-might also help to limit its consumability, and thus the chance of appropriation.

However, there is another take on these issues of sustainability. As painful as it might be when a space or event disappears-and we certainly hope that the Bangkok Biennial will see many future iterations - maybe the counter-hegemonic potential of independent art organising does not primarily reside within the art system. Maybe social practices that emerge within art settings play a role beyond their boundaries as well. McKee (2017, p. 26) thus stresses that the transformative nature of "artists as organisers" might not lay in their "expressing a radical tendency within the established institutions of the art system...but rather when it takes on an 'organizing function' in the creation of a new collective assemblage of authorship, audience, and distribution networks embedded in political struggle." Similarly, as one of the initiators of the Bangkok Biennial suggests:

Our hypothesis was that you don't need to ask permission from anyone [to organise a biennial]....And it was true. And the very simple act of naming it and promoting it and letting people know about it opened the channel for a lot of people to express whatever they wanted....In a society like Thailand, where that is not common or encouraged, it helps to effect a way of acting.

On its own, of course the Bangkok Biennial has limited counter-hegemonic potential outside the art system. However, as an event of social organising with the development of communities at its core, this biennial adds common spaces to a network of similar spaces inside and outside the art world that together provide an infrastructure for radical transformation. If we look at it in this way, in the end it might not be too problematic if a specific independent art event like the Bangkok Biennial ceases to exist, as long as others inside and outside the art system continue to take up this role as common organisers. 
In Thailand's recent political protests, artists certainly have played their role amongst others, and networks developed in common art spaces provide a basis for political and social organising next to networks developed elsewhere (see also van Meeteren \& Wissink, in press). Examples of such organising include the Free Arts (ศิลปะปลดแอก) network, a group of activists from the cultural sphere that emerged in 2020 to support political protests, and the People Taking Care of Ourselves Group (กลุ่มคนดูแลกันเอง), a volunteer group working out of an artist studio providing food and health care services to construction workers-mainly Southeast Asian migrants - that were locked in their work camps as a consequence of government-imposed Covid-19 restrictions. In itself, the art background of the people involved in these initiatives is probably not very important; after all, as Colectivo Situaciones (2007) argues, at times of crisis and protest "professional" identities, including the identity of the artist, lose their importance. However, at the same time, these initiatives rest on networks that emerged in common art spaces. As one protester from the art world suggests, "they just use the people that they know." Another organiser agrees, stressing that "of course, all the people I know come through the art community." In this light, the Bangkok Biennial is part of a much wider network of common spaces that together provide the physical infrastructure for the development of counter-hegemonic action. And while the specific art spaces, practices, or events that contributed to this infrastructure might not live on in the future, outside of art, the commoning that was at their basis might well have a lasting effect.

\section{Acknowledgments}

We thank the biennial organisers, pavilion organisers, and interviewees with whom we have been talking in preparation of this text, as well as the reviewers who responded to earlier drafts of this article for generously sharing their time and knowledge.

\section{Conflict of Interests}

The authors declare no conflict of interests.

\section{References}

Baker, C., \& Phongpaichit, P. (2017). A history of Thailand (3rd ed.). Cambridge University Press.

Bangkok Biennial. (2018). Guide to pavilions: 01.0730.09.18. https://www.bangkokbiennial.com/2018edition

Basualdo, C. (2003). The unstable institution. In P. O'Neill (Ed.), Curating subjects (pp. 39-52). Open Editions.

Berlant, L. (2016). The commons: Infrastructures for troubling times. Environment and Planning $D$ : Society and Space, 34(3), 393-419. https://doi.org/10.1177/ 0263775816645989
Boltanski, L., \& Esquerre, A. (2020). Enrichment: A critique of commodities. Polity Press.

Chachavalpongpun, P. (Ed.). (2014). "Good coup" gone bad: Thailand's political developments since Thaksin's downfall. ISEAS.

Chaitawat, B., Haila, A., \& Vuolteenaho, J. (2021). Religious land as commons: Buddhist temples, monastic landlordism, and the urban poor in Thailand. The American Journal of Economics and Sociology, 80(2), 585-636. https://doi.org/10.1111/ajes.12382

Colectivo Situaciones. (2007). Politicizing sadness. https://chtodelat.org/b8-newspapers/12-58/ politicizing-sadness

Connors, M. (2005). Ministering culture: Hegemony and the politics of culture and identity in Thailand. Critical Asian Studies, 37(4), 523-551. https://doi.org/ $10.1080 / 114672710500348414$

Dardot, P., \& Laval, C. (2019). Common: On revolution in the 21st century. Bloomsbury.

De Angelis, M. (2017). Omnia sunt communia: On the commons and the transformation to postcapitalism. Zed Books.

Ferrara, F. (2015). The political development of modern Thailand. Cambridge University Press.

Fraser, N. (2014). Behind Marx's hidden abode: For an expanded conception of capitalism. New Left Review, 86, 55-72. https://newleftreview.org/issues/ii86/ articles/nancy-fraser-behind-marx-s-hidden-abode

Gardner, A. (2019, August 21). What does a biennale do beyond the exhibition? [Speech]. The 2nd Setouchi Asia Forum, Takamatsu, Japan.

Green, C., \& Gardner, A. (2016). Biennials, triennials, and documenta: The exhibitions that created contemporary art. Wiley Blackwell.

Hardt, M., \& Negri, A. (2009). Commonwealth. Harvard University Press.

Isager, L., \& Ivarsson, S. (Eds.). (2010). Saying the unsayable: Monarchy and democracy in Thailand. NIAS Press.

Kapur, G. (2018). Proposition avant-garde: A view from the South. Art Journal, 77(1), 87-89. https://doi.org/ 10.1080/00043249.2018.1456253

McKee, Y. (2017). Strike art: Contemporary art and the post-occupy condition. Verso.

Montesano, M. J., Chachavalpongpun, P., \& Chongvilaivan, A. (Eds.). (2012). Bangkok May 2010: Perspectives on a divided Thailand. ISEAS.

Mouffe, C. (2013). Agonistics: Thinking the world politically. Verso.

Mouffe, C. (2018). For a left populism. Verso.

Nair, V. (2019). Womanifesto: A biennial art exchange in Thailand. Southeast of Now: Directions in Contemporary and Modern Art in Asia, 3(1), 147-171.

Oren, M. (2014). Biennials that promote an "emancipatory politics." World Art, 4(2), 277-305. https://doi. org/10.1080/21500894.2014.961646

Phongpaichit, P., \& Baker, C. (1998). Thailand's boom and bust. Silkworm Books. 
Poshyananda, A. (2021, May 3). Contemporary mediocrities. Bangkok Post. https://www.bangkokpost. com/life/arts-and-entertainment/2109495/ contemporary-mediocrities

Shelby, H. (2021). Commoning or being commoned? Institutions, politics, and the role of the state in collective housing policy in Bangkok, Thailand. Planning Theory. Advance online publication. https://doi.org/ 10.1177/14730952211037372

Spencer, K. A. (2015). Why the rich love Burning Man. Jacobin. https://www.jacobinmag.com/2015/ 08/burning-man-one-percent-silicon-valley-tech

Stavrides, S. (2016). Common space: The city as commons. Zed Books.

Suehiro, A. (1992). Capitalist development in postwar Thailand: Commercial bankers, industrial elite, and agribusiness groups. In R. McVey (Ed.), Southeast Asian capitalists (pp. 35-64). SEAP.

Teh, D. (2017). Thai art: Currencies of the contemporary. NUS Press.

Teh, D. (2018). Artist-to-artist: Chiang Mai Social Installation in historical perspective. In D. Teh \& D. Morris (Eds.), Artist-to-artist: Independent art festivals in Chiang Mai (pp. 12-47). Afterall Books.

van Meeteren, L., \& Wissink, B. (2019). What should biennials do? Zine for the Bangkok Art Book Fair. Poop Press.

van Meeteren, L., \& Wissink, B. (2020). Biennials and hegemony: Experiences from the Thai Laboratory.
OnCurating, 46, 431-449. https://on-curating.org/ issue-46-reader/biennials-and-hegemonyexperiences-from-the-thai-laboratory.html\#. XxKTIPJS_OQ

van Meeteren, L., \& Wissink, B. (in press). Artists as organisers: Remarks on the counter-hegemonic potential of cultural commoning in Thailand. In T. Lijster, P. Gielen, \& L. Volont (Eds.), Rise of the common city: Cultural commoning in urban conditions. ASP Editions.

Virno, P. (2004). A grammar for the multitude. Semiotext(e).

Volont, L. (2020). Shapeshifting: The cultural production of common space. Faculty of Social Sciences of the University of Antwerp.

Volont, L., \& Smets, P. (2021). The politics \& aesthetics of the urban commons: Navigating the gaze of the city, the state, the market [Paper session]. The RC21 Conference 2021. https://www.uantwerpen.be/en/ conferences/rc21-conference-2021/programme/ paper-sessions

Volont, L., \& Smets, P. (2022). The politics and aesthetics of the urban commons: Navigating the gaze of the city, the state, the market. Social Inclusion, 10(1), 84-90.

Winichakul, T. (2000). The quest for "siwilai": A geographical discourse of civilizational thinking in the late nineteenth and early twentieth-century Siam. The Journal of Asian Studies, 59(3), 528-549. https://doi.org/ $10.1017 /$ S0021911800014327

\section{About the Authors}
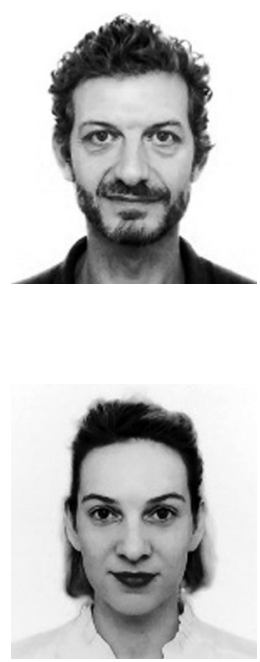

Bart Wissink is associate professor urban studies and urban policy at the Department of Public Policy, City University of Hong Kong. With co-author Lara van Meeteren, he has a research-based practice, focusing on issues relating to the social role of art and independent contemporary art initiatives in East and Southeast Asia. He is co-creator of coming soon • เร็ว ๆ นี้ (www.comingsoonbkk.com) for the 2018 Bangkok Biennial, and of a related research project that informs this contribution. For the 2020 Bangkok Biennial, together with co-author Lara van Meeteren, Ariane Kupferman-Sutthavong, and Sina Wittayawiroj, he organised the inappropriate BOOK CLUB (www.facebook.com/inappropriateBOOKCLUB).

Lara van Meeteren is an independent contemporary art researcher and organiser. With co-author Bart Wissink, she has a research-based practice, focusing on issues relating to the social role of art and independent contemporary art initiatives in East and Southeast Asia. Lara is co-creator of coming soon • เร็ว ๆ นี้ (www.comingsoonbkk.com) for the 2018 Bangkok Biennial, and of a related research project that informs this contribution. For the 2020 Bangkok Biennial, together with co-author Bart Wissink, Ariane Kupferman-Sutthavong, and Sina Wittayawiroj, she organised the inappropriate BOOK CLUB (www.facebook.com/inappropriateBOOKCLUB). 